\title{
Rest in peace, Bob Tollison
}

\author{
William F. Shughart II $^{1}$
}

Received: 22 January 2017/Accepted: 31 January 2017/Published online: 14 February 2017

(C) Springer Science+Business Media New York 2017

Robert Dewitt Tollison, former coeditor of this journal (along with Friedrich Schneider, followed by Peter Kurrild-Klitgaard, in Europe; Bob handled manuscripts submitted from "the rest of the world" jointly with the late Charles K. Rowley), former president of the Public Choice Society, Director of the Center for Study of Public Choice at George Mason University and J. Wilson Newman Professor of Economics at Clemson University at the end of his academic career, passed away suddenly at the age of 73 on October 24, 2016. Such a bare-bones sketch of Bob Tollison's scholarly life and times hardly does justice to a man who had a major impact on the direction of the literatures of public choice and applied microeconomic theory more broadly, supervised the doctoral dissertations of scores of graduate students, taught principles of economics and public choice to countless undergraduates and published several hundred peer-reviewed journal articles plus many books and monographs. Neither does it allow people either inside or outside the ivory tower's walls who did not know him personally to grasp Bob's astonishing intellectual energy, his work habits, his generosity, the friendships he forged with colleagues and coauthors, or the important influences he had on the academic careers of many other scholars.

It is for those reasons that I contacted and received commitments from 14 of Bob's closest friends and most frequent coauthors soon after news of his passing reached me by telephone and email on that black Monday morning last October, asking them to contribute personal remembrances of him, to summarize some of the research projects on which they had collaborated or that they found to be especially noteworthy, or simply to write about their interactions with Bob on campus, at professional conferences, in governmental posts, or other venues. I have written two such essays myself (Shughart 2017a, b), but Bob was such a giant in the economics profession-a proverbial force of nature-that I alone could not possibly comprehend-or even know about—all of the ways in which he affected other lives and career trajectories.

William F. Shughart II

william.shughart@usu.edu

1 Utah State University, Logan, UT, USA 
The following articles, in my judgment, fulfill that objective. We begin with the texts of two eulogies delivered at Bob Tollison's funeral in Clemson, South Carolina, on Friday, October 28, 2016. The first is by Bob's son, Mark, now a county attorney in Greenville, South Carolina, which is located cheek-to-jowl with Spartanburg, Bob's birthplace and where he starred as a high-school basketball player. The second is by Robert ("Bobby") McCormick, now the dean of Clemson University's business school and a Ph.D. student at Texas A\&M University when Bob was the head of the economics department there in the mid-to-late 1970s. Those truly were halcyon days in College Station, Texas, as I have written elsewhere (Shughart 2017b), a time when an incredibly bright and productive group of faculty members and graduate students were present at the creation of an economics department that had not before (and, in some senses, never has since) been equaled, except perhaps at the University of Chicago or the University of California, Los Angeles, in their bygone heydays.

Following those two eulogies are papers, organized alphabetically by the surnames of their respective authors, that speak to Bob's various intellectual and personal influences on the many scholars with whom he interacted at various points in his own academic career. First in line is a paper by Pete Boettke, who focuses on Bob's contributions to the by-now extensive literature on rent seeking, an idea arising from the fertile mind of Gordon Tullock, Bob's colleague at the Center for Study of Public Choice at, first, Virginia Tech University in Blacksburg, and, afterwards, following the Center's move to George Mason University, in Fairfax, Virginia. In the course of his essay, Boetkke documents Bob Tollison's impact on him personally as well as Bob's generosity towards younger (at the time) budding scholars like Michael Munger, who later made important contributions to both public choice and political science.

The next essay is by Roger Congleton, now on the faculty of West Virginia University, but Bob's former colleague at the Center for Study of Public Choice as well as one of Bob's successors as Director of that Center. Congleton discusses Bob's monumental productivity as a scholar and then summarizes his approach to analyzing legislative, judicial and bureaucratic processes, which consisted of assuming that all such actors are rationally self-interested, that public policies mostly are about wealth or income redistribution rather than about protecting private property rights or individual liberties, and that equilibriums in political markets are determined largely by the influence various special interest groups can marshal to secure desired benefits or to avoid unwelcome costs. As Bob once put it bluntly, in politics "ideas don't matter, only interest-group pressure does". Congleton ends with some personal reflections on Bob as a colleague, Center director and mentor.

That essay is followed by one coauthored by Nicole Crain and (William) Mark Crain, the latter being, if my memory does not fail, the first of Bob's Ph.D. students at Texas A\&M. Their paper, titled "Robert's Rules" (pun intended), lays out the strategies Bob adopted to prosper in the academic publication "game". While not every young economist hoping to earn promotion and tenure at the college or university level will follow Bob's rules, as laid out by the Crains, they paved Bob's (and many of his coauthors') roads to success. Hard and consistent work is the key here. As Bob once said to me, academic economists "don't take vacations". In making promotion and tenure decisions of their junior colleagues, department heads (or chairs) and senior faculty members almost always confront tradeoffs between the quantities and qualities of the junior faculty's scholarly productivities. Bob Tollison maximized and excelled along both of those margins.

Next up is William Dougan. Bill was Bob's student early in both of their respective academic careers and then Bob's colleague at Clemson when Bob passed away late last 
year. Bill's unique perspective as somewhat of the bookend to Bob's professional activities allows him to document the consistency in everything Bob accomplished throughout his too-short life as a teacher, a researcher and a mentor of younger scholars. When things fell apart at the University of Mississippi in the late $1990 \mathrm{~s}^{1}$ - I and then-acting business school dean Keith Womer had managed to lure Bob to Oxford 5 years beforehand-Bill Dougan apparently was instrumental in convincing Bob to return to Clemson. (Bob had been on the faculty there for a few years in the mid-1980s, before moving on to George Mason). Not counting my graduate school days in College Station, I was, of course, deeply disappointed to lose Bob as a colleague for the third time (sequentially at the Federal Trade Commission, Clemson and George Mason; it was I who moved the last time around). In hindsight, though, Bob and certainly Clemson were much better off.

Scarcely older than most of his students at the time, Bob Ekelund became an assistant professor at Texas A\&M in the late 1960s and already had been promoted to full when Bob Tollison joined the faculty there in 1974 . The two have been collaborating on academic research projects ever since. Along with Robert Hébert of Louisiana Lafayette and, then, like Bob Ekelund, professor emeritus at Auburn, the "three Bobs" leveraged their joint interests in economic history and the history of economic thought to contribute two important books on the industrial organization of the Medieval Catholic Church (Sacred Trust, Oxford University Press 1996) and Christianity more generally (The Marketplace of Christianity, MIT Press 2006). Bob Ekelund and Bob Tollison also coauthored two books on mercantilism, the first in 1982 (Mercantilism as a Rent-Seeking Society), followed in 1997 by Politicized Societies, both published by Texas A\&M Press, and then one on The Economic Origins of Roman Christianity (University of Chicago Press 2011). Another book on the market for American art in collaboration with Auburn's John Jackson will be published by Oxford University Press in 2017.

Bob Ekelund's essay recounts the intellectual energy Bob Tollison brought to College Station, their enduring and productive joint scholarly enterprise, which began with a research "shop" Bob Tollison assembled from faculty colleagues and graduate students at Texas A\&M, and the pleasures of collaborating with him over the ensuing decades at long distance, spurred often by early morning telephone calls placed by Bob Tollison without regard to differences in time zones. Bob Tollison coauthored academic journal articles more frequently with some of his other students and colleagues, but I doubt that he published more printed pages with anyone else than Bob Ekelund, even if one ignores the seven editions of their principles of economics textbook.

\footnotetext{
1 The crisis at Ole Miss is almost too unbelievable for most people not on the ground to credit. A new business school dean had been hired-a mrketing professor from a then-Big-12 school—whose number 1 priority was to transfer the Department of Economics to the College of Liberal Arts. Aided and abetted by an ignorant provost (an attorney with no publications other than a couple of law review articles) and a university Chancellor, also trained in the law, but at least holding a master's degree, the dean's Exhibit A for why economics did not belong in the business school was an article published by the "three Bobs" (see below) in a 2002 issue of the Journal of Political Economy, titled "An Economic Analysis of the Protestant Reformation". What in the world, the dean asked, does that event have to do with business education? Of course, Martin Luther had triggered competitive entry against the Catholic Church, the world's first multinational corporation, by, among other things, bypassing priestly middlemen between God and the Christian faithful, eliminating auricular confession (and the accompanying price discriminatory forgiveness of sins), along with the sale of indulgences, and removing purgatory as a barrier on the pathway to salvation for unbaptized souls, for which money could be extracted from surviving family members in payment for the eventual transition of deceased loved ones to the Pearly Gates. If such analyses don't apply to business decision-making, neither I nor Bob Tollison and his coauthors know what does.
} 
Dwight Lee, now retired from an academic career ending at Southern Methodist University, is nearly as old a friend and colleague of Bob Tollison as Mark Crain, Bob Ekelund, Bobby McCormick and me, all present in College Station at roughly the same time, along with many of Bob's other lifelong collaborators, not excluding Bob's wife Anna, who worked then in Texas A\&M's economics department. Dwight and Bob both were at George Mason's Center for Study of Public Choice in the mid-1980s. Dwight and I crossed paths there for 1 year only, I think, before Dwight departed for a faculty post at the University of Georgia. (I've told Dwight on more than one occasion that he moved on to Georgia after realizing that he could not compete with me as Bob's coauthor!) In any event, Dwight's essay is very intimate, recounting advice from Bob that helped Dwight cope with a crisis in his own personal life. Bob Tollison often allowed criticisms to roll off him like water from a duck's back, but he always helped his friends and remained loyal to the people he knew and liked without reservation. I have witnessed flashes of temper from Bob, but he never allowed his anger to destroy longstanding personal relationships, preferring to forgive and to forget or to "move on" in George W. Bush fashion rather than engage in conflicts with those rare people (academic administrators, usually) who caused him pain.

An essay contributed by Mike Maloney, twice Bob's colleague at Clemson (Clemson 1.0 and 2.0, according to one of their friends), focuses on the energy Bob brought to Sirrine Hall, the economics department's campus home. Echoing other contributors to these pages, Maloney emphasizes Bob's work habits, his classroom teaching skills, and his generosity to other scholars, but also tells us how much fun Bob was to be around day in and day out.

Two of the essays published herein refer, but not exclusively, to Bob's experiences at the Federal Trade Commission during President Ronald Reagan's first term in office. Those essays are contributed, respectively, by James C. Miller III and, violating the principle of alphabetical ordering, Bruce Yandle. Both of those essays highlight Bob Tollison's multi-tasking capacities. Whether or not he had been appointed to administrative posts, as economics department head at Texas A\&M, Director of the Federal Trade Commission's Bureau of Economics (BE), or as Director of George Mason's Center for Study of Public Choice, Bob possessed the unique ability to carry out his administrative responsibilities while simultaneously sustaining an active scholarly research agenda.

Jim Miller, the first professional economist ever to serve as the Chairman of the fivemember Federal Trade Commission and one of Bob Tollison's doctoral student classmates at the University of Virginia, joins Bruce Yandle, who wrote his doctoral dissertation under Professor Miller at Georgia State University and served as the Executive Director of the FTC then, to write about Bob Tollison's contributions to helping redirect the FTC's mission during President Ronald Reagan's first term, which involved me as Bob's "special assistant", tasked with composing memos from him to the commission as a whole, typically recommending dropping pending FTC actions against private sector defendants. ${ }^{2}$ Along the way, Bob and I published our first coauthored academic journal article (in the American Economic Review) on the US Federal Reserve System as an example, owing to its institutional funding mechanism, of an expansionist Washington, D.C., bureaucracy.

\footnotetext{
${ }^{2}$ Collaborating with Richard S. Higgins, Bob and I likewise were instrumental in shutting down the commission's "Line of Business" data collection program. That program required companies in the private sector (above a certain size) to maintain an extra set of books so as to report to the FTC information on revenues and costs segregated by major product line. We wrote that the program not only duplicated data already being collected for the Census of Manufactures, published every five years, but was of limited usefulness to scholars and policymakers because of the theoretical impossibility of allocating capital and other joint costs (e.g., managerial time and effort) across the various lines of business of multiproduct firms.
} 
Fred McChesney, Michael Munger and Raymond ("Skip") Sauer round out the contributions to this series of essays honoring Bob Tollison's memory. All of them celebrate in various ways Bob's influences on the trajectories of their own academic careers. As I read (and reread) those essays and the other contributions published herein, I am brought to tears as the memories of Bob's influences on my career and those of many others crowd into my head.

Bob Tollison wrote his dissertation under James Buchanan at the University of Virginia (over one summer, as I have been told) and was the leading member of the "second generation" of public choice scholars, following Professor Buchanan as well as being as much of an imperialist as Gordon Tullock was in applying public choice and microeconomics principles to explain human behavior in the world at large, including the domains of professional and "amateur" (collegiate) sports, religion, constitutions and many of the other realms of collective decision making. It is as a scholar, collaborator, colleague and friend that Bob is most sorely missed by those who had the privilege and good fortune of knowing him.

Everyone represented herein-and many others-were shocked and wounded irreparably by Bob Tollison's sudden and unexpected death last fall. Bob taught us all how to be better price theorists, how to extend the model of rational human behavior in new and sometimes surprising directions, how to have fun in the process and, occasionally, how to write science fiction by dabbling in the literatures of macroeconomics or monetary theory.

Bob Tollison was treasured by almost everyone who knew him and I cannot read or reread any of the essays published herein without tears in my eyes. It is to Bob's memory and to his surviving family_-wife and helpmate Anna, their children Mark and April, and their own children, Bob and Anna's grandchildren-to which the following essays are dedicated with sadness and with much love.

Acknowledgements I benefitted from comments on an earlier draft by Mark Crain, Bob Ekelund, Mike Munger, Bruce Yandle and other contributors to these essays, none of whom should be held responsible for the final content, for which I alone am to blame.

\section{References}

Shughart II, W. F. (2017a). Robert D. Tollison, In memoriam. The Independent Review. (in press).

Shughart II, W. F. (2017b). Robert D. Tollison, A personal remembrance. Southern Economic Journal, $83(3), 630-636$. 